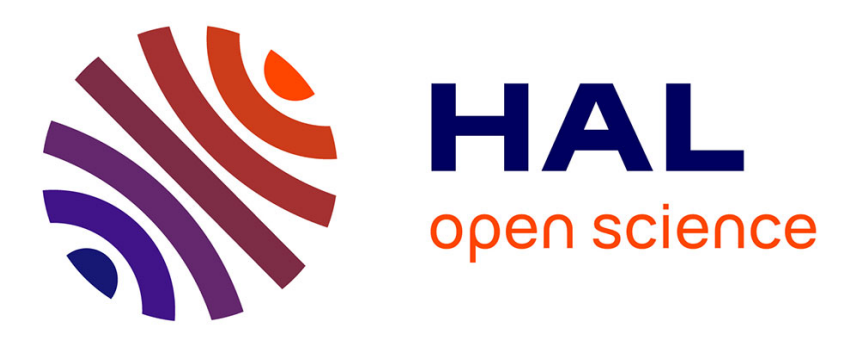

\title{
Intergenerational transmission in consumer behaviour: An integrative conceptual framework and future research directions
}

\author{
Samuel Guillemot
}

\section{- To cite this version:}

Samuel Guillemot. Intergenerational transmission in consumer behaviour: An integrative conceptual framework and future research directions. Recherche et Applications en Marketing (English Edition), 2018, 33 (2), pp.93-114. 10.1177/2051570718774009 . hal-02466675

\section{HAL Id: hal-02466675 \\ https://hal.univ-brest.fr/hal-02466675}

Submitted on 25 Mar 2021

HAL is a multi-disciplinary open access archive for the deposit and dissemination of scientific research documents, whether they are published or not. The documents may come from teaching and research institutions in France or abroad, or from public or private research centers.
L'archive ouverte pluridisciplinaire $\mathbf{H A L}$, est destinée au dépôt et à la diffusion de documents scientifiques de niveau recherche, publiés ou non, émanant des établissements d'enseignement et de recherche français ou étrangers, des laboratoires publics ou privés. 


\title{
Intergenerational transmission in consumer behaviour: an integrative conceptual framework and future research directions
}

\author{
Samuel GUILLEMOT, Univ Brest, LEGO, Quimper, France
}

\begin{abstract}
The concept of intergenerational transmission has given rise to a heterogenous body of research in consumer behaviour. It has been mobilised in domains as varied as consumer socialisation and heritage disposition. This article proposes an integrative conceptual framework for the intergenerational transmission of consumer behaviour. This framework has emerged from an interpretation of Erikson's (1959) theory of human personality development. Its first contribution is that it links the developmental concerns of the younger and older generations (learning, differentiating, taking care and preserving) around the notion of intergenerational capital. Its second contribution is that it puts forward the concepts of sociocultural, economic, psychological and genetic capital, which serve to enrich and clarify the nature of intergenerational capital. Finally, it opens up new research directions, including a much-needed focus on the central role of the 'pivot' generation (the 30-65 age group) and on taking into account the concept of attachment (Bowbly, 1978) in the study of the effect of inherited psychological resources on the adoption of consumer practices.
\end{abstract}

Keywords: Learning, gift, exchange, education, heritage, intergenerational influences, legacy, preservation, socialisation, solidarity, intergenerational transmission

TO CITE: GUILLEMEOT S. (2018), INTERGENERATIONAL TRANSMISSION IN CONSUMER BEHAVIOUR: AN INTERGRATIVE CONCEPTUAL FRAMEWORK AND FUTURE RESEARCH DIRECTIONS, RECHERCHE ET APPLICATIONS EN MARKETING (ENGLISH EDITION), 33 (2), 93-114,

Fundamental trends in our contemporary societies are disrupting traditional intergenerational links and the associated transmission phenomena. With an ever-increasing lifespan resulting in the coexistence of four and even five family generations, these changes are primarily demographic in nature (Préel, 2005). Social changes such as the valorisation of the individual, the extension of adolescence and old age (Attias-Donfut and Segalen, 1998) and the now central place of the child in the many and varied modern types of households ${ }^{1}$ (Ayadi and Gollety, 2012) have destabilised the place and role of each generation. In addition to this, the current economic and political conditions foster precarity and greater intergenerational dependence (Tavoillot et al., 2011). It is vital we understand these intergenerational transmission phenomena because they lie at the heart of human behaviour. All our choices and decisions are based on a repository of resources and dispositions that have been shaped by previous generations (Trizzulla et al., 2016) and guided by what we hope to pass on to future generations (Urien and Kilbourne, 2011).

In the field of consumer behaviour, there are two main conceptual frames of reference for the study of intergenerational transmission. The first concerns consumer socialisation, in other words, the process whereby individuals acquire the skills, knowledge and attitudes they need to fulfil their roles as consumers in the marketplace (Ward, 1974). Intergenerational transmission within this framework refers to the transmission of immaterial objects through implicit/explicit interactions within the different family generations. The focus is placed on child consumers (e.g. Ward, 1974), adolescents (e.g. Lueg et al., 2006) and young adults (e.g. Moore et al., 2002). The second, more recent framework has been developed since the 2000s in response to the ageing demographic. Researchers have begun to use theories on psychological ageing and preparation for death to study the transmission of material objects,

\footnotetext{
${ }^{1}$ Stepfamilies, single-parent families, same-sex families, etc.
} 
particularly through the disposition of heritage in the form of single or repeated transactions (Price et al., 2000; Urien, 2003).

The research on intergenerational transmission has covered a variety of objectives (BourcierBéquaert and de Barnier, 2010). Some studies have aimed to promote the education of future consumer citizens (Hémar-Nicolas and Rodhain, 2012) or to understand how the changes in intergenerational links influence consumer practices (Karanika and Hogg, 2016). Others have adopted a more managerial mission, which involves enabling brands to become established in individual and family histories (Decoopman and Gentina, 2013; Kessous et al., 2015; Ladwein et al., 2009) or businesses to design and adapt products and services to respond to our need to pass on a legacy (Guillemot, 2015; Malas, 2012; Urien and Guiot, 2007). This level of variety in the existing research can be explained by a broad vision of intergenerational transmission. The concept of 'intergenerational transmission' conjures up ideas of a movement, passage or exchange between generations (Gire, 2003). It is conceived 'as a process that involves a giver [i.e. the transmitter, for example a parent] and a receiver [for example a child], who are linked by an interaction procedure' ${ }^{2}$ (Lahaye et al., 2007: 109). Intergenerational transmission is thus understood in different acceptations in consumer behaviour (table 1), depending on the nature of the object being transmitted (immaterial or material), the process (implicit/explicit interactions or single/repeated transactions) and the actors involved (familial or demographic generation).

Faced with this fragmented use of the concept of intergenerational transmission in consumer behaviour, this article proposes an integrative conceptual framework. This framework is essential if we are to deliver a more comprehensive interpretation of intergenerational transmission, a dynamic phenomenon made up of reciprocal influences between different generations. For example, the grandparent/grandchild relationship is not just limited to questions of heritage; it also responds to socialisation logics (Derbaix et al., 2015; JosionPortail, 2014). In addition, by interacting with their peers, children can experiment with new norms, introducing them into their homes and thus enriching the consumer practices of their parents (Gollety, 1999; Gollety et al., 2012).

The construction of this integrative conceptual framework is set out in this article as follows. First, Erikson's (1959) theory of human personality development is mobilised as an interpretative framework for understanding intergenerational transmission. This Eriksonian interpretation allows us to showcase the four different positions an individual can occupy in terms of their intergenerational capital, namely learning from other generations, differentiating from other generations, taking care of other generations and preserving for other generations. Intergenerational capital is understood here as a repository of material and immaterial assets that are transmitted and which evolve from one generation to the next (Trizzulla et al., 2016). Second, in consumer behaviour, knowledge is expressed in relation to these four positions. Our Eriksonian interpretation reveals the notions of sociocultural, economic, psychological and genetic capital, which expand and clarify the nature of intergenerational capital. The integrative conceptual framework of intergenerational transmission consequently takes shape when the different components of intergenerational capital (sociocultural, economic, psychological and genetic) are expressed in relation to the developmental concerns of the givers and receivers (learning, differentiating, taking care and preserving). The article closes with a discussion of the contributions made and the possible future research directions opened up by this integrative conceptual framework.

\footnotetext{
${ }^{2}$ This and all subsequent quotations from French sources have been translated into English.
} 
Table 1: The different acceptations of intergenerational transmission in consumer behaviour.

\begin{tabular}{|c|c|c|c|}
\hline & Approaches & Descriptions & Illustrations in consumer behaviour \\
\hline \multirow[t]{2}{*}{$\begin{array}{l}\text { The nature } \\
\text { of the } \\
\text { objects } \\
\text { transmitted } \\
\text { (what?) }\end{array}$} & $\begin{array}{l}\text { Immaterial } \\
\text { objects }\end{array}$ & $\begin{array}{l}\text { Attitudes, preferences, } \\
\text { knowledge, skills, consumer } \\
\text { practices, etc. }\end{array}$ & $\begin{array}{l}\text { Attitudes passing from one generation to the } \\
\text { next (e.g. scepticism towards advertising, } \\
\text { Obermiller and Spangenberg, 2000), } \\
\text { preferences (e.g. preferred brands, Moore and } \\
\text { Lutz, 1988), consumer 'savvy' (Nancarrow et } \\
\text { al., 2008) or consumer practices (Moore et al., } \\
\text { 2002) }\end{array}$ \\
\hline & $\begin{array}{l}\text { Material } \\
\text { objects }\end{array}$ & $\begin{array}{l}\text { Valuable objects, objects with } \\
\text { sentimental but no financial } \\
\text { value, money, etc. }\end{array}$ & $\begin{array}{l}\text { End-of-life disposition of objects by way of } \\
\text { heritage (Price et al., 2000) }\end{array}$ \\
\hline \multirow{4}{*}{$\begin{array}{l}\text { The } \\
\text { processes } \\
\text { (when and } \\
\text { how?) }\end{array}$} & $\begin{array}{l}\text { Explicit } \\
\text { interactions }\end{array}$ & Learning, initiation, etc. & $\begin{array}{l}\text { Parents' educational practices in relation to } \\
\text { consumption (Ayadi and Gollety, 2012); the } \\
\text { transmission of know-how and knowledge } \\
\text { through personal accounts (Guillemot, 2015) }\end{array}$ \\
\hline & $\begin{array}{l}\text { Implicit } \\
\text { interactions }\end{array}$ & $\begin{array}{l}\text { Influences through absorption } \\
\text { and/or through a process of } \\
\text { observation/imitation }\end{array}$ & $\begin{array}{l}\text { Visible brands and/or those consumed in a } \\
\text { routine and frequent context are often } \\
\text { consumed by the children when they leave the } \\
\text { family home (Schindler et al., 2014) }\end{array}$ \\
\hline & $\begin{array}{l}\text { Repeated } \\
\text { transactions }\end{array}$ & Exchanges, sharing, etc. & $\begin{array}{l}\text { The exchange and shared consumption of } \\
\text { clothes between mothers and daughters } \\
\text { (Decoopman and Gentina, 2013) }\end{array}$ \\
\hline & $\begin{array}{l}\text { Single } \\
\text { transactions }\end{array}$ & Gifts, legacies, etc. & $\begin{array}{l}\text { The gift of a luxury watch from father to son } \\
\text { (Kessous et al., 2015); legacies and financial } \\
\text { transfers (Krebs et al., 2012; Malas and Guiot, } \\
\text { 2010) }\end{array}$ \\
\hline \multirow{2}{*}{$\begin{array}{l}\text { The } \\
\text { generations } \\
\text { (who?) }\end{array}$} & $\begin{array}{l}\text { Family } \\
\text { generations }\end{array}$ & $\begin{array}{l}\text { Generational succession } \\
\text { according to filial ties: } \\
\text { children/parents/grandparents }\end{array}$ & $\begin{array}{l}\text { The role of the children (Gollety, 1999), } \\
\text { parents (Beatty and Talpade, 1994) and /or } \\
\text { grandparents (Derbaix et al., 2015; Josion- } \\
\text { Portail, 2014) in the construction of } \\
\text { consumption-related practices/knowledge }\end{array}$ \\
\hline & $\begin{array}{l}\text { Demographic } \\
\text { generations }\end{array}$ & $\begin{array}{l}\text { Generational succession } \\
\text { according to age and life } \\
\text { cycle: young/active/retired or } \\
\text { past/future generations }\end{array}$ & $\begin{array}{l}\text { Consumer practices as an act of preserving } \\
\text { living conditions for future generations } \\
\text { (Lacroix and Jolibert, 2015; Urien and } \\
\text { Kilbourne, 2011) }\end{array}$ \\
\hline
\end{tabular}

\section{INTERGENERATIONAL TRANSMISSION: AN ERIKSONIAN INTERPRETATION}

Erikson saw the psychosocial development of the individual as a continuous, lifelong process. His studies $(1950 ; 1959)$ therefore offer an interesting interpretative framework for organising research on consumer behaviour from the socialisation of children to the heritage disposition practices of older adults. Erikson was an American psychoanalyst (born at the beginning of the $20^{\text {th }}$ century) who specialised in children's psychosocial development. Most notably, he conducted research in the 1930s in the Native American Sioux and Yurok reserves in the United States. Erikson realised that the origin of some of the psychosocial problems experienced by the Native Americans could be found in the gap between their tribes' histories and traditions and their ways of life in the reserves. Based on his observations, which he compared and transposed to Western culture, he formed his theory of personality development. He highlighted the psychosocial, cultural and historic aspects of the development of the ego 
and stressed that personality is developed within a social reality, in other words within one or more groups with which we have not only a shared past but also a shared future.

Shared past refers here to family and social relations and the cultural traditions that shape our behaviour. Erikson put forward a model of child and adolescent development, drawing parallels between that and the Freudian theories of developmental stages (oral, anal, etc.). Erikson's model also took into account an individual's interactions with their environment, which become increasingly complex as a child grows (incorporating first the mother, then both parents and then the family, school, friends, and so on). More specifically, Erikson (1950) proposed a series of six stages during which the child and then the adolescent must find a balance between two opposing poles. For example, during the first phase of development (0-18 months), the newborn must find a balance between unconditional attachment to its mother (trust) and protection against the outside world (mistrust). The approach proposed in this article does not consist in addressing the different stages of development but rather in drawing inspiration from the model more generally by focusing on intergenerational relationships. In this sense, we are interested in the situation with regard to intergenerational capital (a repository of material and immaterial assets), which is transmitted and which evolves from one generation to the next. The child will, first of all, absorb this capital, and then, as they grow, they will draw on the different resources and dispositions, which they will articulate according to their identity concerns (Trizzulla et al., 2016). This is, incidentally, the approach proposed by Ladwein et al. $(2009)^{3}$ in their study of the consumer socialisation of daughters by their mothers. The authors describe how a repository of habits and knowledge is constructed during childhood (most notably concerning practices and uses, brand choices, products and distribution channels), which serves as a lifelong ready frame of reference when purchasing or consuming.

The benefit of Erikson's (1959) approach is that it links this shared past with the vision of a shared future. Erikson was profoundly marked by the Second World War. He was born in Germany and saw his Jewish-origin family emigrate to the United States in response to the Nazi regime. As such, he was convinced that education and the transmission of collectively shared values were essential to the healthy development of individuals and societies. He therefore extended his theory, adding two further stages. These relate to the psychosocial developmental concerns of adults, namely taking care of intergenerational capital and preserving aspects considered to be essential. The notion of transmission therefore becomes fundamental in his theory because it links the developmental concerns of the younger generations with those of the older generations.

In summary, an Eriksonian interpretation of intergenerational transmission allows us to identify four basic positions with regard to intergenerational capital in which each generation relies on the others for their own development. First, the individual must learn the necessary skills and techniques for living in society from previous generations. They then have to differentiate themselves by developing their own identities and goals in life. Following this, they are ready to take care of the generations that come after them, and, finally, they seek to preserve the elements that could be useful to them. Table 2 presents these concerns and links them to consumer behaviour research and the main problematics developed in these studies.

\footnotetext{
${ }^{3}$ Ladwein et al. (2009) introduced the notion of 'transgenerational equity' since their focus was exclusively on the receivers' (the daughters') point of view. In this article, the prefix 'inter' (intergenerational capital) is preferred because the viewpoints of both the givers and receivers are being considered.
} 
Table 2: Developmental concerns and positions with regard to intergenerational capital (adapted from Erikson, 1959).

\begin{tabular}{|c|c|c|c|}
\hline Developmental concerns & Life stage & Close relationships & $\begin{array}{l}\text { Research on consun } \\
\text { behaviour }\end{array}$ \\
\hline $\begin{array}{l}\text { Learning from other } \\
\text { generations }\end{array}$ & & \multirow{2}{*}{$\begin{array}{l}\text { Parents, rest of the } \\
\text { family, then } \\
\text { gradually friends and } \\
\text { other referents } \\
\text { (school, etc.) }\end{array}$} & \multirow[b]{2}{*}{$\begin{array}{l}\text { Educational practic } \\
\text { and intergeneration } \\
\text { influences within th } \\
\text { home }\end{array}$} \\
\hline $\begin{array}{l}\text { Learning skills and } \\
\text { techniques; Assimilating } \\
\text { values and valorised }\end{array}$ & $\begin{array}{l}\text { Principally } \\
\text { childhood }\end{array}$ & & \\
\hline
\end{tabular}

Main problematics developed

Identifying the content of family learning (Gollety et al., 2012; Moore et al., 2002; Schindler et al., 2014; Ward, 1974)

Understanding the family learning training processes (Ayadi and Gollety, 2012; Carlson and Grossbart, 1988; Mandrik et al., 2005)

behaviours

(school, etc.)

Understanding the roles and contributions of different family members (Beatty and Talpade, 1994; Derbaix et al., 2015; Gollety, 1999; JosionPortail, 2014)

Differentiating from other generations

Defining and developing personal and social

identities; Defining goals and choosing a direction in life
Principally adolescence and early adulthood

Peers, friendship groups, individuals with similar identities
The impact and contribution from transmitted resources to the construction of consumer values and practices

\section{Understanding intergenerational borrowing and the rejection of} consumer practices (Decoopman and Gentina, 2013; Ladwein et al., 2009)

Clarifying the role of naturally available resources:

> sociocultural (Ladwein et al., 2009; Moore et al., 2002)

$>$ psychological (Chaplin and Roedder-John, 2010; Richin and Chaplin, 2015; Rindfleisch et al., 1997)

genetic (Simonson and Sella, 2011)

\section{Taking care of other}

generations

Guiding and taking care of the younger and/or older generations adulthood

(midlife)

Preserving for other generations

Preserving what really matters from being lost through death or oblivion (heritage)

\section{Principally}

Children, family, the individual's community

Intergenerational practices of solidarity
Understanding the mechanisms and motivations linked to economic and material transfers in moments of crisis (Karanika and Hogg, 2016; Noble et al., 2004)

Describing the characteristics and role of family caregivers (Mahur and Moschis, 1999)

Understanding the receivers' motivations and choices through the givers (Price et al., 2000; Guillemot 2015; Malas and Guiot, 2010)

Identifying the conveyors of heritage meanings (Guillemot and Urien, 2010; Price et al., 2000; Rieunier and Urien, 2011)
Principally the latter stage of life
Family, individuals with similar identities, society, the world constructing and transmitting heritage
Understanding the receivers' perceptions and uses of heritage as resources (Curasi et al., 2004; Kessous et al., 2015) 
Almost one hundred consumer behaviour studies were mobilised to produce this state-ofthe-art summary. They were identified in the following way. First, the databases of 45 of the most important French- and English-language marketing journals ${ }^{4}$ were searched using the keywords 'intergenerational' and 'intergenerational transmission' (and their French equivalents). A total of 39 articles relating specifically to 'intergenerational transmission' were identified for the period 1970-2017. Second, the bibliographies of these articles were examined, and the principal works on which the articles were based were integrated into our summary. This allowed us to identify the two analytical frameworks presented in the introduction, namely the consumer socialisation of children through the transmission of immaterial assets (with Ward (1974) as the founding article) and older adults' disposition of heritage through the transmission of material assets (with Price (2000) as the founding article). The bibliographic search was then diversified using, on the one hand, keywords such as 'socialisation, 'influences' and 'learning' (and their French equivalents) to identify studies relating to the transmission of immaterial assets and, on the other, keywords such as 'heritage' 'exchanges', 'gifts' and 'legacies' (and their French equivalents) for the transmission of material assets. The studies (which included articles, books, theses and conference proceedings) retained were those that examined relationships involving at least two distinct generation members (family and/or demographic).

A summary of the knowledge presented in these works is set out in the next four sections, which correspond to the four intergenerational capital positions (table 2).

\section{LEARNING FROM OTHER GENERATIONS}

The first phase of personality development consists in absorbing intergenerational capital. This is, in other words, when personality develops in relation to other generations (row 1 of table 2). In Erikson's original theory, this is an essential developmental phase, made up of a number of stages in accordance with cognitive, motor and social development (Erikson, 1950). This phase mainly occurs during childhood. The child needs the previous generations in order to be able to decipher and understand social codes and acquire essential techniques and skills. Initially passive and dependent on their parents, the child's world is gradually opened up to other reference sources, such as the rest of the family, school and different media. In consumer behaviour, studies dealing with this subject form part of the field of study relating to consumer socialisation (Ward, 1974). Intergenerational transmission, which is understood here as the passing on of immaterial objects within family generations, is one of the most important means of socialisation. Children have a substantial amount of time to learn the attitudes and behaviours of their parents and to integrate them as norms (e.g. Moschis and Churchill, 1978; Moschis and Moore, 1979; Ward et al., 1977). For the past four decades, researchers have been attempting to understand the family's role in the consumer's social learning and, more particularly, to find answers to these two questions: What is transmitted? And how? (Moore et al., 2002; Ward, 1974). Their studies have highlighted the existence of a repository of intangible assets relating to the 'consumer savvy' that is transmitted from one generation to the next, which we will call here 'sociocultural capital'.

The first subsection below presents this sociocultural capital and specifies its contents. The second focuses on the types of influences behind its intergenerational transmission.

\footnotetext{
${ }^{4}$ These journals were identified by the FNEGE (Fondation Nationale pour l'Enseignement de la Gestion des Entreprises, or French Foundation for Management Education) as the leading scientific journals in the field. The FNEGE relies on a scientific body, composed of all the French scholarly management sciences associations, to draw up a classification of scientific journals (updated every three years). These 45 leading scientific journals in the field of marketing rely on a peer-reviewed committee composed of recognized researchers and a rigorous doubleblind evaluation procedure. The journals are classified according to a set of objective criteria, such as their presence in the rankings established by international evaluation bodies, and a set of bibliographical indices (impact scores with and without self-citations, $\mathrm{h}$ index, SJR indicator).
} 


\section{The notion of sociocultural capital}

In the 1970s, researchers observed a certain continuity between the consumer behaviours of parents and their children. The notion of sociocultural capital came into play when these continuities were viewed as a repository of skills, knowledge and attitudes relating to consumption that had been developed since childhood (Ladwein et al., 2009). This view extended the sociological theory of the sociocultural transmission of the agent (Bourdieu, 1994; Lahaye et al., 2007) to the field of consumption. This sociological theory postulates that the norms, practices, habits and symbols that are useful for living in society are transmitted from one generation to the next through established social groups such as the family and school (Bourdieu, 1979). Many empirical studies have set out to identify and measure the continuities in consumption generated by filiation. These studies' methodologies have mainly been based on subjective participant self-assessments or on comparative evaluations of the giver/receiver dyad (table 3). They have allowed researchers to identify intergenerational continuities relating to knowledge (e.g. in the set of brands mentioned, e.g. Moore et al., 2002), 'savvy' (e.g. Mandrick et al., 2005; Nancarrow et al., 2008) and consumer practices (e.g. from the shopping planning strategy to the way in which purchases are stored and consumed [e.g. Moore-Shay and Lutz, 1988]). Intergenerational reproduction also includes certain attitudes such as preferences (e.g. Derbaix et al., 2016; Moore et al., 2002; Siddiqui et al., 2012), brand loyalty (e.g. Cai, Zhao and He, 2015), sensitivity to promotions (e.g. Schindler et al., 2014), sensitivity to innovation (Cotte and Wood, 2004), scepticism towards advertising (e.g. Obermiller and Spangenberg, 2000), and so on. Generally speaking, consumption can be considered a vector for the passing on of values from one generation to the next (e.g. materialism [Moschis and Churchill, 1978; Moschis and Moore, 1979]).

Table 3: Principal methodologies for identifying intergenerational continuities and changes.

\begin{tabular}{|c|c|c|}
\hline Approaches & Methods & Illustrations \\
\hline \multirow{2}{*}{$\begin{array}{l}\text { Self-assessment } \\
\text { These methods presuppose that the } \\
\text { individuals questioned are aware of } \\
\text { the transmission mechanisms, on the } \\
\text { one hand, and that they have a precise } \\
\text { idea of the other generation's } \\
\text { consumption, on the other. For this } \\
\text { reason, they are recommended either } \\
\text { as an initial approach or for relatively } \\
\text { common consumer products }\end{array}$} & $\begin{array}{l}\text { Quantitative } \\
\text { analysis }\end{array}$ & $\begin{array}{l}\text { - Questionnaires using subjective evaluation of generational } \\
\text { continuities (e.g. Heckler et al., 1989; Childers et Rao, 1992) } \\
\text { - Development of 'standard' skills, knowledge and attitudes scales } \\
\text { aimed at enabling study comparisons (e.g. IGEN Scale, } \\
\text { Viswanathan et al., 2000) }\end{array}$ \\
\hline & $\begin{array}{l}\text { Qualitative } \\
\text { analysis }\end{array}$ & $\begin{array}{l}\text { - Semi-structured interviews } \\
\text { - Potential use of techniques allowing researchers to facilitate the } \\
\text { recollection and contextualisation of memories, for example by } \\
\text { using projective techniques (e.g. Downey and Ellis, 2008) or } \\
\text { accompanying participants in their consumer activities (e.g. } \\
\text { Moore et al., 2002) }\end{array}$ \\
\hline \multirow{3}{*}{$\begin{array}{l}\text { Comparative perspectives } \\
\text { These methods consist in collecting } \\
\text { the viewpoints of at least two family } \\
\text { members. The mother/daughter (e.g. } \\
\text { Beatty and Talpade, 1994) and } \\
\text { father/son dyads are the most } \\
\text { frequently studied on account of } \\
\text { gender identity }\end{array}$} & $\begin{array}{l}\text { Qualitative } \\
\text { analysis }\end{array}$ & $\begin{array}{l}\text { - Double interview study (e.g. Kessous and Chalamon, 2014) } \\
\text { - Phenomenological, interpretative or thematic analyses of } \\
\text { qualitative data }\end{array}$ \\
\hline & $\begin{array}{l}\text { Correlation } \\
\text { model }\end{array}$ & $\begin{array}{l}\text { - Correlation analysis of responses to similar questions posed to } \\
\text { both parents and children (e.g. Arndt, 1971; Moore-Shay and } \\
\text { Lutz, 1988; Obermiller and Spangenberg, 2000). } \\
\text { - The random dyads procedure, which is based on permutation tests, } \\
\text { allows researchers to isolate the family effect from other } \\
\text { environmental variables (e.g. Mandrick et al., 2005, Schindler, } \\
\text { Lala and Corcan, 2014) }\end{array}$ \\
\hline & Prediction model & $\begin{array}{l}\text { - Regression models where the independent variables come from } \\
\text { the giver and the dependent variables from the receiver (e.g. Cai } \\
\text { et al., 2015) }\end{array}$ \\
\hline
\end{tabular}




\begin{tabular}{|c|c|c|}
\hline These methods allow researchers to & $\begin{array}{l}\text { Longitudinal } \\
\text { model }\end{array}$ & $\begin{array}{l}\text { - The study of biographical trajectories using measurements at } \\
\text { regular intervals on the same subjects has not been developed in } \\
\text { consumer behaviour studies but is often cited as a possible } \\
\text { research direction (Lee et al., 2013) }\end{array}$ \\
\hline $\begin{array}{l}\text { transmitted practices and attitudes } \\
\text { according to life trajectories }\end{array}$ & $\begin{array}{l}\text { Retrospective } \\
\text { model }\end{array}$ & $\begin{array}{l}\text { - Life stories approach (Ladwein et al., 2009) } \\
\text { - Other methodological tools used to increase the accuracy of } \\
\text { retroactive measurements over short recall periods (e.g. life } \\
\text { history calendar, Axim et al., 1999) }\end{array}$ \\
\hline
\end{tabular}

\section{Types of influences behind the transmission of sociocultural capital}

There are two types of influences that explain the intergenerational transmission of sociocultural capital. These are the implicit influences that underlie learning through observation/imitation and the explicit influences embodied in educational practices and parenting styles. Whether implicit or explicit, researchers have highlighted the reciprocal nature of these intergenerational influences.

Implicit influences. Consumer skills, knowledge and attitudes are acquired gradually and mainly implicitly through an observation/imitation mechanism (Ayadi and Gollety, 2012). Throughout their development, children have many opportunities to observe adults' attitudes, preferences and behaviour and to integrate them as norms (Moschis and Churchill, 1978; Moschis et al., 1984). Hence, the probability that children will adopt their parents' preferences is higher for the consumption of products and brands that are 'visible' in the home (Moore et al., 2002), for routine and frequent behaviours (Schindler et al., 2014) and for concrete rather than abstract attitudes (Moschis and Churchill, 1978; Mandrik et al., 2005). Researchers endeavour to contextualise the place of family learning in the development of children's cognitive abilities (Roedder-John, 1999) and other sources of socialization such as peer, media and school influences. When children grow up, family influence thus remains preponderant for products and consumption within the private context of the home (Childers et Rao, 1992) but is outranked by peer influence when it comes to products and consumption of a social or public nature (Beatty and Talpade, 1994).

Explicit influences. While parental consumer education mainly operates implicitly through observation and imitation, the transition to explicit learning forces parents to reflect on the contents of their teaching and to pay attention to the coherence between discourse and their actual behaviour. In this respect, Ayadi and Gollety (2012) have identified a number of roles parents play when they are teaching children how to consume. The role of educator consists in formally explaining choices and decisions and justifying rejections. The role of consumption stimulator autonomises children by involving them in family decisions. Finally, the role of mediator puts into perspective and facilitates the understanding of information that comes from other socialisation sources such as the media and peers. In this sense, researchers are interested in the quality of communication within the home (Cai et al., 2015; Moschis and Moore, 1979; Schindler et al., 2014; Viswanathan et al., 2000) and in the impact of different parenting styles on the social learning of consumption (Beatty and Talpade, 1994; Carlson and Grossbart, 1988; Heckler et al., 1989; Wiman, 1983). In summary, parents who give their children responsibility are more likely to explain their choices, which facilitates the children's integration and understanding of the rules of knowing how to consume (Carlson et al., 1994). In contrast, parents who are seeking harmony and/or who either do not or only minimally explain their choices are likely to cause confusion in their children (Kim et al., 2009).

Reciprocal implicit and explicit influences. Studies have shown the dynamic nature of the social learning of consumption through exchanges and reciprocal (implicit or explicit) influences. The phenomenon of 'reverse socialisation' refers to the enrichment of family 
consumption practices through the children. By interacting with other social spheres than those of their parents, children experiment with new norms and practices, which they can introduce into their own homes (Gollety, 1999; Gollety et al., 2012). Children's opinions are taken on board particularly when it comes to lifestyle changes (Lueg et al., 2006) and products and/or behaviours linked to new technologies (Shah and Mittal, 1997). However, as the traditional model of the family evolves, studies of the influences within the father/son and mother/daughter gender dyads are gradually being expanded to also incorporate the influence of other family members (Cotte and Wodd, 2004) such as siblings and grandparents. Grandparents participate in their grandchildren's socialisation and are generally more 'flexible' than the parents (JosionPortail and Michel, 2016). In terms of content, they contribute to the emergence of knowledge about nature, culture and sporting activities and to the development of a taste and preference for certain products/activities (Derbaix et al., 2015).

\section{DIFFERENTIATING FROM OTHER GENERATIONS}

Once the individual has assimilated the norms and references of intergenerational capital, they begin to gradually seek to stand out and differentiate themselves from previous generations (row 2 of table 2). This is a difficult developmental task, and individuals draw on the resources they already have available. In terms of consumer behaviour, researchers have focused on the resources transmitted (most notably by the parents) and on their contribution to the formation of consumer values in children and the consumer practices choices they make.

The first subsection below looks at sociocultural resources. The studies presented are still rooted in the consumer socialisation trend, but they focus more on the recipient generation (Ladwein et al., 2009; Moore et al., 2002). The problematic consists in determining why the receiver mobilises, rejects and evolves certain skills, knowledge and attitudes derived from their inherited sociocultural capital. The second and third subsections highlight the respective effects of inherited psychological and genetic resources on consumer choices and decisions. The studies presented in these two subsections introduce the psychological and genetic components of intergenerational capital.

\section{The individualisation of sociocultural capital}

Sociocultural capital serves as a reference tool in purchasing or consumption situations (Ladwein et al., 2009). Individuals adapt and reinterpret what has been transmitted to them according to their environment, their identity choices and the direction they want to take in life (Trizzulla et al., 2016). For example, a daughter leaving the family home will tend to reject some of her mother's practices, particularly those associated with a domestic role, in order to mark her singularity. However, these rejections are often only partial and circumstantial. When the daughter becomes a mother herself, she tends to reinvest the transmitted practices (Ladwein et al., 2009). These behaviours can be explained by the sociological theory of the sociocultural transmission of the actor (Lahaye et al., 2007), which postulates that the individual has the ability to become aware of the influence that the past exerts on them (Attias-Donfut, 2000). The individualisation of sociocultural capital is therefore a key notion. It allows the individual to retain their identity and history while integrating the changes that happen around them (Trizzulla et al., 2016). The reciprocal and dynamic nature of these intergenerational influences should be noted here too. By showing that some mothers can modify their clothing brand and/or retailer preferences through social and symbolic comparisons with their daughters, Decoopman and Gentina (2013) demonstrated that parents' sociocultural capital evolves under their children's influence. 


\section{The notion of psychological capital}

As sociocultural considerations pass through the generational cycle, they generate relationships between people. The social link and affect therefore become important transmission vectors. We therefore introduce here the notion of 'psychological capital', which extends the psychological theories on attachment (Bowbly, 1978). Psychology and social psychology research is based on the fact that the parental support and attention an individual receives during childhood has a lasting impact on their psychological development in terms of self-esteem and perceived (in)security (Bowbly, 1978). These psychological styles tend to repeat themselves, forcing successive generations into a virtuous or vicious circle. The vicious circle is difficult to break out of because the individuals involved are not necessarily aware of the phenomenon (Kaës et al., 2003; Winter, 2012). The individual who is faced with psychological insecurity or low self-esteem will seek reassurance by adopting behaviours that they assume to be valorising (Chaplin and Roedder John, 2010). Hence, it has been shown that the perception of a feeling of psychological insecurity (linked to an absence of parental attention/support during childhood) can be considered an antecedent variable in the adoption of materialistic values (Felfoul, 2014; Richins and Chaplin, 2015; Robert et al., 2003; Rindfleish et al., 1997; Rindfleisch et al., 2009). Similarly, a low level of self-esteem can predict an adolescent's level of materialism (Chaplin and Roedder-John, 2010) and even the tendency of mothers to co-consume and exchange clothes with their adolescent daughters (Gentina et al., 2013). In this sense, it is possible to consider that psychological capital can influence the way in which an individual will adopt and integrate the skills, knowledge and attitudes derived from their sociocultural capital.

\section{The notion of genetic capital}

The studies presented above highlight the intergenerational impact of sociocultural, economic and psychological issues. However, these influences are contained within a framework that is biologically predetermined. Studies in behavioural biology - the study of the effects of genes on behaviour (Plomin et al., 1999) - tend to show that an individual will structure their environment according to their genetic capital (Johnson et al., 2009). Genetic capital thus refers to genetic predispositions to engage in choices/behaviours (Plomin et al., 1999). Genes do not, of course, directly influence behaviour. They do so by 'coding' sequences of amino acids to form proteins. These proteins 'create the skeletal system, the muscles and the endocrine, immune, digestive and nervous systems, the last of which is the most important in terms of behaviour' (Plomin et al., 1999: 61). However, the fact that all behaviours have an inherited component does not mean that genes always have a significant effect. Indeed, the variance in aptitudes and behaviours due to genetics generally fluctuates between $25 \%$ and $30 \%$ and does not exceed 50\% (Turkheimer, 2000).

Simonson and Sela (2011) sought to determine the influence of genes on consumer choices and decisions by subjecting pairs of monozygotic twins (100\% identical genetic inheritance, $\mathrm{n}=220$, mean age 46.6 years) and dizygotic twins ( $50 \%$ shared genetic inheritance, $n=140$, mean age 49 years) to a series of tests and decision problems (decision-making and behavioural decision measures). Their results indicated a very low (often non-significant) genetic heritability in the majority of consumer choices and decisions except when notions of 'prudence' and 'risk-taking' were involved. These results suggest that genetic effects may be linked to general personality tendencies (such as the risk-taking tendency here), which can manifest in identity choices and consumer decision-making. However, these results remain 
exploratory and require supplementary studies in order to be able to clarify the role of genetic capital in consumer choices and decisions.

\section{TAKING CARE OF OTHER GENERATIONS}

Adult life is the period when the links from the past, the present and the future become connected and intertwined. It marks a turning point, when an individual fully realises the importance of intergenerational links and the value of their heritage. Erikson uses the term 'generativity' to refer to a communion instinct that pushes individuals to invest a part of themselves in order to contribute to the wellbeing of other generations (row 3 of table 2). Within this configuration, intergenerational transmission can be seen as a particular form of giving involving actors from different generations. Consequently, the obligation to give back is deferred over time. We take care of our children's generation to 'repay the debt' owing to previous generations; and the children then 'repay' that debt by looking after their parents when they get old (Attias-Donfut and Segalen, 1998). In terms of consumer behaviour, aside from the previously mentioned educational practices, the thematics of intergenerational solidarity have been little developed in the research. Indeed, it is not yet possible to define it as a research area with clearly identifiable origins in the same way that we can define consumer socialisation, which originates from Ward's 1974 study. There are, nevertheless, a small number of studies in the literature that focus on the financial and material support that individuals give to their adult children (e.g. Karanika and Hogg, 2016) and/or their elderly parents (e.g. Mahur and Moschis, 1999) and on the impact this has on consumer practices.

The first subsection below thus introduces a new component of intergenerational capital economic capital - which is based on the economic sciences' view of capital. The second subsection considers the impact that this economic capital has on consumer behaviours.

\section{The notion of economic capital}

In economics, the notion of capital includes the material assets and financial flows transmitted across the generations (Piketty, 2013). The economic sciences have shed light on the reproduction movements of this capital through time and have noted a return of societies dominated by the weight of heritage (Arrondel and Masson, 2011). As Piketty (2013: 601) explained: 'inasmuch as the twenty-first century will be characterised by a reduction in growth (demographic and economic) and a high return on capital (in a context of heightened competition between countries to attract capital), at least in those countries where such an evolution will occur, heritage will probably regain a similar importance to that enjoyed in the nineteenth century'. Aside from the problematics linked specifically to inheritance, which will be addressed later in the article, many intergenerational transfers happen over the course of an individual's lifetime. These flows are difficult to grasp because, on the one hand, they are barely visible and, on the other, they are the product of a multitude of motivations, including caregiving as a gesture of solidarity, presents given for pleasure or for tax benefits (Gale and Scholtz, 1994; Masson, 2009). This could explain the lack of academic studies on the subject. However, a family's economic resources and material living standards influence the consumption of the children emerging from the family home. For example, the presence or absence of significant dispositions determines many family and personal choices, such as the choice of housing (Piketty, 2013). This is why, at the end of the 1970s, Moschis and colleagues used a family's socioeconomic status in their attempts to understand consumer socialisation (Moschis and Churchill, 1978; Moschis and Moore, 1979). 


\section{The influence of economic capital on consumer behaviours}

Compared with the economic sciences, which study the overall movements of capital, studies of consumer behaviour provide a vision that is centred on the individual by exploring the motivations and meanings they give for transmitting economic capital. The small number of studies that have addressed this subject in our discipline have highlighted several forms of solidarity. 'Descendant' solidarity refers to a situation in which adults receive material and financial support from their parents (e.g. Karanika and Hogg, 2016). This is the most common form of solidarity given that $90 \%$ of intergenerational financial flows pass from the older to the younger generation (Cordier et al., 2007). 'Ascendant' solidarity refers to children taking care of their elderly parents (e.g. Mahur and Moschis, 1999). In both cases, the role of persons central to the family - the caregivers - is highlighted. Mahur and Moschis (1999) revealed a form of familial and social determinism in the adoption of this role. The person who takes care of others in the family is most often predisposed to this by their gender (female), their ranking among the siblings (the oldest) and/or their geographic proximity to the people needing assistance. These solidarity situations create ambivalent feelings that range from love for the givers to shame for the receivers (Karanika and Hogg, 2016). These feelings impact on everyday consumer behaviours in the sense that those involved tend to give up a part of their personal identity for the benefit of their familial and collective identities (Karanika and Hogg, 2016). These results suggest therefore that the economic capital disposed of for reasons of intergenerational solidarity will influence the way in which individuals individualise their sociocultural capital through their consumer choices and practices. This point requires a more detailed examination and will be developed within the discussion of future research directions at the end of the article.

\section{PRESERVING FOR OTHER GENERATIONS}

When the idea and the reality of death begin to be felt (during old age, last row of table 2), an individual will fear that everything they know and all that they have built will disappear with them. They engage in a series of reflections, which takes the form of multiple assessments. These allow them to reconstruct the past according to the image they want to leave behind after their death (Butler, 1963). These in-depth reflections will shed new light on certain life events and highlight the salient aspects of the individual and familial identities that they seek to transmit in order to preserve them from dying out (McAdams, 2001; Vaillant, 2002). In terms of consumer behaviour, one of the first articles to focus on this subject was that of Price et al. (2000), who showed how older adults preserve personal and familial meanings through the disposition of their objects. Since Price et al.'s (2000) work, a number of studies have examined heritage construction and disposition practices. These have confirmed the preponderant role of meanings associated with heritage (Guillemot, 2015). The first subsection below sets out how these meanings are embodied in objects derived from economic capital (e.g. in singular objects). The second presents scenarios in which these meanings are rooted in sociocultural capital (e.g. in practices).

\section{Economic capital in heritage}

As mentioned in the section on economic solidarities, researchers have adopted an individual-centred approach in order to shed light on economic heritage disposition choices. The aim has been to identify personality variables or salient motivations and propose some levers of action to businesses and organisations linked to the construction/disposition of heritage (Urien and Guiot, 2007). Hence, Malas (Malas, 2012; Malas and Guiot, 2010) showed that the way in which older adults perceive the future directly impacts their financial choices in 
terms of, for example, saving and making lifetime gifts and wills. When individuals have no children, associations and other collective institutions can claim to be recipients of their testamentary dispositions if they manage to develop similar values to those of the potential donors (Krebs et al., 2012; Rieunier and Urien, 2011).

The majority of studies on the disposition of economic capital concern the transmission of objects with a strong sentimental value. These are unique and differentiated objects that are seen as 'special' or inalienable possessions because they are linked to specific life events and/or the collective family history (Grayson and Shulman, 2000). Hence, individuals transfer personal and familial meanings to objects and then pass these objects on to the next generation to preserve a part of their identity (table 4). Price et al. (2000) have uncovered a duality between these logics of identity and relational logics, which is that individuals seek to identify the receivers most likely to preserve the meanings associated with the transmitted objects. Very often, the choice of receiver obeys the laws of family reproduction, in other words, an object will be transmitted, for example, from father to son, from mother to daughter or to the eldest sibling (Price et al., 2000). Such objects/practices produce social hierarchies within families whereby certain members assume the role of 'guardian' - caretaker - for these heritages and feel they have been entrusted with the task of preserving them and transmitting them in turn when the time comes (Curasi et al., 2004). The receiver is not obliged to accept the heritage, but if they do so, the associated meanings can be used as mobilizable resources in the construction of their identities. We should make a distinction here between the meanings associated with heritage (memories, a story, etc.) and the affective and psychological elements crystallised by the transmission process. The role of receiver can be experienced positively or negatively, as a burden or duty linked to a feeling of debt (Curasi et al., 2004). For example, Kessous et al. (2015) showed that a father's gift of a luxury watch to his son brought about a logic of comparison and generated a series of obligations in the son (e.g. sharing the father's passion, having to transmit the watch himself, living up to the father's expectations, etc.).

Table 4: The transmission of inalienable possessions.

\begin{tabular}{lll}
\hline $\begin{array}{l}\text { Why are certain possessions } \\
\text { inalienable? }\end{array}$ & An inalienable possession is a physical or digital \\
Belk, 1988; Belk et al., 1988; Belk, & embodiment (corporally indexical association) of a place, \\
2013; Grayson and Shulman, 2000; & person, period of time or event \\
Richins, 1994 & $-\quad \begin{array}{l}\text { Individuals personally invest in maintaining the meaning of } \\
\text { these objects } \\
\text { - The possession is valorised for its meaning independently } \\
\text { of its financial value } \\
\text { Most often, the value is only symbolic. When the object has } \\
\text { financial value (property, family business, etc.), it will be } \\
\text { inalienable if it serves well-defined objectives in the future }\end{array}$ \\
\hline
\end{tabular}

What is the role of an inalienable possession?

-In the case of a possession valorised by an individual Belk, 1988; Curasi, 2011; Price et al., 2000

\footnotetext{
- In the case of a possession valorised by a family Curasi et al., 2004; McCracken, 1988
}

- It allows the individual to reinforce and express their identity, to differentiate themselves from others

- It serves as an anchor and allows the individual to retain a sense of control over change and over passing time

- It gives substance to the family's collective identity and history

- It produces a social hierarchy within the family. Only one person can hold it, but it does not belong to them (they are its guardian, or caretaker) 


\begin{tabular}{|c|c|}
\hline $\begin{array}{l}\text { How should an inalienable } \\
\text { possession be transmitted? } \\
\text { Cours et al., 1999; Price et al., 2000; } \\
\text { Stenvenson and Kates, 2010; Wallendorf } \\
\text { and Arnould, 1991; Young and } \\
\text { Wallendorf, } 1989\end{array}$ & $\begin{array}{l}\text { - The physical transfer of the object often happens during } \\
\text { traditional rites of passage (communion, marriage, etc.) or } \\
\text { rites of progression (birthdays, etc.) } \\
\text { - The transfer can be ritualised from one caretaker to the next } \\
\text { or more spontaneous with or without an exchange on the } \\
\text { meaning } \\
\text { - In all cases, the emotional detachment is not synchronised } \\
\text { with the physical transfer }\end{array}$ \\
\hline $\begin{array}{l}\text { Why is the inalienable status } \\
\text { precarious during the } \\
\text { transmission process? } \\
\text { Bradford, 2009; Epp and Price, 2010; } \\
\text { Kessous et al., 2015; Lastovika and } \\
\text { Fernandez 2005 }\end{array}$ & $\begin{array}{l}\text { - The object will be transferred to a new owner who will } \\
\text { either accept or reject it, but in either case the meaning is } \\
\text { transformed } \\
\text { - The object can be put back onto the market and thus } \\
\text { desacralized }\end{array}$ \\
\hline
\end{tabular}

\section{Sociocultural capital as the conveyor of meanings to be preserved}

Since Price et al. (2000), researchers have attempted to identify other means that individuals use to preserve meanings for other generations. Guillemot (2015), for example, showed that oral and written accounts, conversations and times spent together are the most popular and valorised means of passing meanings on to future generations. These meanings can also be embodied in consumer practices that convey part of the familial and collective identity. Hence, 'grandmother's recipe' (Kessous and Chalamon, 2014) or specific consumer practices can survive through the generations and become family traditions (Castano et al., 2010). We see here similar problematics to those found in consumer socialisation research, particularly those relating to traditions (Hirschman, 1985) and/or the role of grandparents (Derbaix et al., 2015; Josion-Portail, 2014).

While consumer practices can be shaped by traditions from the past, they can also be seen as acts aimed at preserving meanings and a viable world for future generations. For example, Urien and Kilbourne (2011) showed that individuals with a pronounced generative interest (i.e. those who think their actions impact future generations) are more concerned with environmentally responsible behaviour (recycling, sorting waste, etc.) than those with a low generative interest. Extending these studies, Lacroix and Jolibert (2015) developed a measurement scale that identifies consumers who prefer to buy products and services that preserve the living conditions (or do not harm the wellbeing) of future generations.

Guillemot and Urien (2016) explained these demographic intergenerational transmissions by identifying several 'levels' or 'dimensions' to intergenerational capital. The motivations to transmit are 'agentic' when personal meanings derived from the individualisation of intergenerational capital are being passed on. They can be 'familial' when the meanings are linked to an identity, or to a capital shared by the whole family. They can also be 'communal' when it comes to passing on collective meanings linked to intergenerational capital that is shared by a whole community or culture.

\section{DISCUSSION}

As a result of this synthesis of knowledge on consumer behaviour, we are able to propose an integrative conceptual framework of intergenerational transmission (Figure 1). 
Figure 1. Integrative conceptual framework of intergenerational transmission in consumer behaviour.

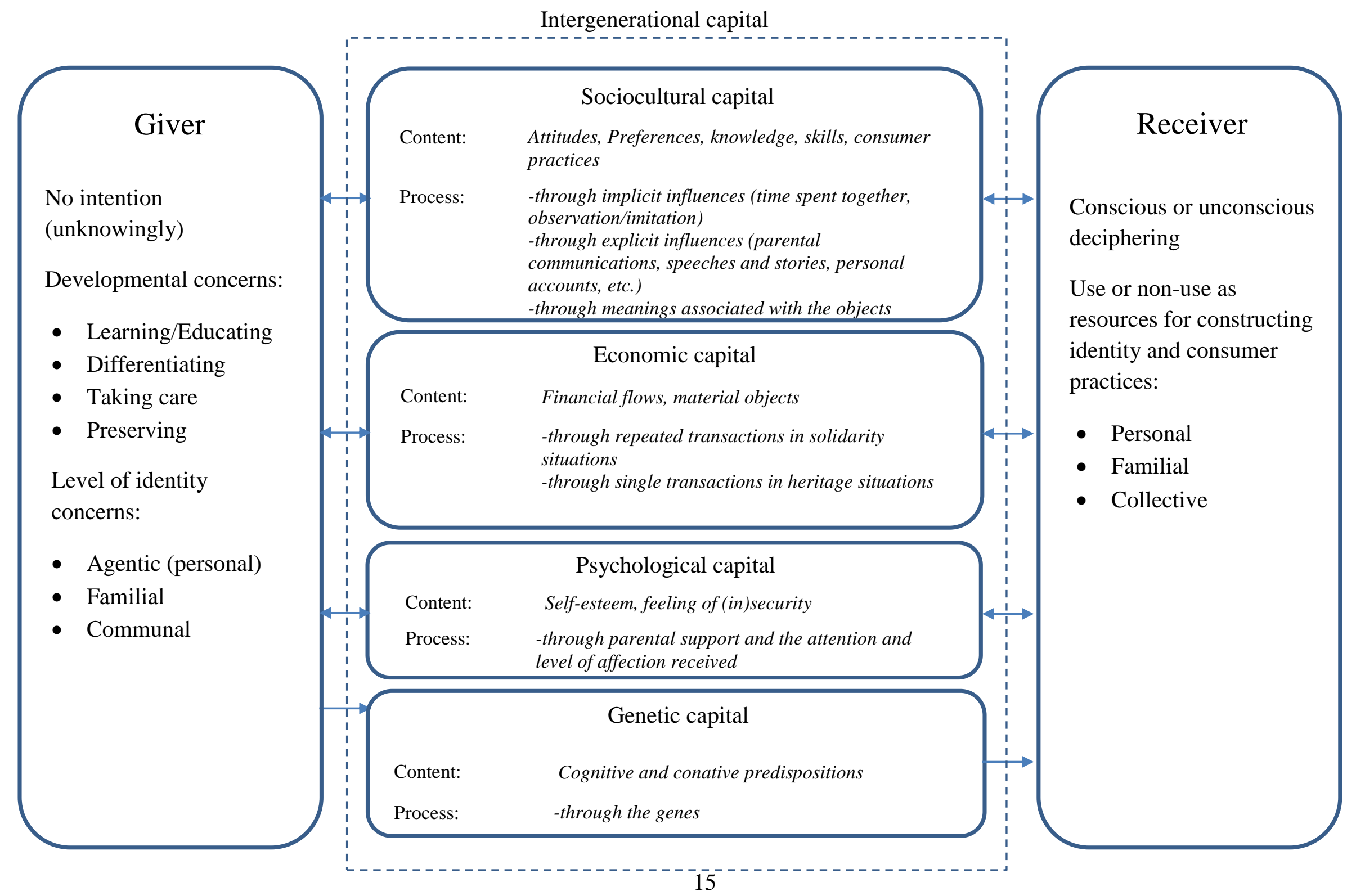


The following subsections show how the three key elements of this conceptual framework can enrich and develop research on the intergenerational transmission of consumer behaviour. The first key element is the articulation of the developmental concerns of those involved in the transmission relating to the intergenerational capital. Intergenerational capital is defined as a repository of material and immaterial objects that are transmitted and which evolve through the generations. The second is that it clarifies the nature of intergenerational capital by distinguishing sociocultural, economic, psychological and genetic resources. The final key element of this conceptual framework is that it highlights the agentic, familial and communal dimensions of intergenerational capital.

\section{The articulation of the developmental concerns of those involved in the transmission}

The proposed conceptual framework's first contribution is that it links developmental concerns relating to both the givers' and receivers' intergenerational capital. The giver will transfer part of their identities (personal, familial and communal) according to their developmental concerns (learning, differentiating, taking care, preserving). The receiver will draw on these resources to construct their own identities and consumer practices, adapting them and allowing them to evolve according to their environment and their own developmental concerns.

Traditionally, consumer behaviour researchers have used the two previously mentioned analytical frameworks to study intergenerational transmission. The socialisation framework is based on young consumers' relationship with their sociocultural capital, and the heritage construction/disposition framework focuses on the relationship older adults have with part of their economic capital. Our integrative conceptual framework highlights the existence of points of convergence between the transmission of tangible and intangible objects. Tangible objects are, in fact, conveyors of meaning and affect that can be transmitted in intangible forms during continuous interactions (conversations, time spent together, consumer practices, etc.). Moreover, it highlights two other developmental concerns in connection with the phenomena of intergenerational transmission, namely differentiating from and taking care of other generations.

In the first case (differentiating from other generations), individuals revisit, reinterpret and remodel their intergenerational capital. Our review of the literature identified only a few consumer behaviour studies on this subject (e.g. Ladwein et al., 2009; Moore et al., 2002). These should be developed further. Digital transformations and the essential transition to sustainable consumer practices will inevitably render some of the consumer practices transmitted by parents ineffective. When the models derived from primary (family) and secondary (school, peers, media) socialisations are in line with one another, the individual will reproduce and adapt their sociocultural capital. However, incompatibility between the two models will force the individual into a period of questioning and conversion, which can even lead to the failure of socialisation (Lahaye et al., 2007). The challenge is therefore to understand why some practices are more anchored than others and to identify the vectors facilitating the change in consumer practices.

In the second case (taking care of other generations), individuals seek to take care of their intergenerational capital. There is very little consumer behaviour research on this subject. A good point of entry would be to focus on the supporting role (called 'caretaker' in heritage research and 'caregiver' in solidarity research) of the 'pivot' generation - the 30 to 65 age group. This generation is the forgotten dimension of intergenerational transmission research. However, it is situated at the 'generational crossroads' in the sense that this age group has to ensure the wellbeing of both their children and their parents as they become increasingly dependent 
(Olsen, 1999). In addition to financial solidarities (transfer of money, loan of accommodation, gift of a car, etc.), the solidarities can therefore take the form of domestic help with daily tasks as well as more symbolic help (networking, exchange of knowledge, spending time together, listening, presence, etc.) (Attias-Donfut, 2000; Masson, 2009). Future research would have to verify the familial determinism hypotheses (gender, siblings ranking, etc.) and examine the emotions involved and the consequences of these solidarities for consumer practices. What is being given up? What is being changed? What services should be developed to support the 'axis of family stability' (Attias-Donfut, 2000)? Everything is in place for the development of research on these thematics because this research will address major economic (increasing precariousness) and societal (the ageing demographic) concerns.

\section{The nature of intergenerational capital}

The second contribution made by this proposed conceptual framework is that it clarifies the nature of intergenerational capital. It distinguishes between the sociocultural, economic, psychological and genetic resources that pass through the generations. These categories should not be seen as mutually exclusive, because, in reality, intergenerational capital is made up of different layers that interact with and overlap one another. Sociocultural capital (consumer skills, knowledge and attitudes) cross the generations through a combination of implicit (observation/imitation) and explicit (educational practices) influences. The transition from one generation to the next is interactive. The older generation teaches the younger generation, who update the practices and, in turn, influence the older generation. Economic capital crosses the generations in the form of financial flows and material objects in solidarity and heritage situations. Some of the economic resources (most notably inalienable possessions) conveys meanings that enrich sociocultural capital. Psychological capital is composed of psychological resources, which individuals can choose to draw on or not. These psychological resources are transmitted through parental support and attention and are embodied in the level of self-esteem and the feeling of perceived (in)security. Recent studies on consumer socialisation suggest that these resources can impact an individual's psychological development, which will, in turn, influence the way in which they integrate and appropriate values, objects and consumer practices. Finally, genetic capital concerns the mobilisation of genetic predispositions in choices/behaviour. This has a special status since the transfer is only one-way.

The conceptual framework proposed here suggests that taking into account the effects of interactions between these different inherited resources will enrich our understanding of the phenomena of intergenerational transmission. While the nature of sociocultural capital is well documented in consumer behaviour, the same cannot be said for economic resources. Moreover, even less attention has been paid to psychological and genetic resources. The next three paragraphs set out future research suggestions for taking these into account.

As far as economic capital is concerned, research has mainly been focused on the transmission of objects with sentimental value. There have been few studies conducted on financial flows and material living conditions. However, economic capital strongly determines and influences the living conditions and familial and personal choices of those who receive it (Piketty, 2013). We need to gain a deeper understanding of these mechanisms of influence through a study of the direct effects of economic capital on consumer practices or of the indirect effect via the development of specific value. Lahaye et al. (2007), for example, showed that people in an unfavourable economic environment develop specific personality characteristics (a critical, reflexive and creative approach that is underdeveloped). This raises the question of whether the intergenerational reproduction of consumer practices might be more frequent when economic capital is underdeveloped 
The concept of attachment (Bowbly, 1978) used in psychology and more particularly in psychiatry and clinical psychology studies enriches our reflection and allows us to better understand the role of psychological resources. According to Bowbly, the affective connections forged in childhood have a determining influence on the way in which children perceive their environment through the trust they place in it and their levels of empathy and self-esteem. Hence, if the attachment need is met in an individual, they will be able to develop generosity, sharing and empathy behaviours, such as giving, more easily. However, an attachment need that is not met results in an adoption of behaviours that are not socially valorised (compulsive behaviour, espousal of undesirable values). Hence, intergenerational transmission is not always accompanied by positive effects. It can also be a vehicle for negative behaviours. At an operational level, it should therefore be possible to indirectly check the influence of psychological resources on undesirable behaviours through the effects of self-confidence, empathy level and self-esteem.

Finally, methodologies based on comparison studies of twins (identical and non-identical, brought up together and/or separately) allow us to clarify the nature of interactions between genetic capital and the environmental development conditions of the individual (Johnson et al., 2009). In practical terms, this involves subjecting a set of twins to questionnaires and comparing their responses while isolating effects attributed to genetic capital from those inherent to sociocultural and economic resources (linked to the shared environment, which refers to living and education conditions) as well as to psychological resources (based on a non-shared environment, which refers to personal experiences and the twins' feelings). These methods offer satisfactory results in behavioural biology, however they are difficult to implement, and they suffer from validity biases related to the sample sizes. This presents a major challenge, therefore, but as Harari (2015: 277) pointed out: 'Scientists are increasingly inclined to argue that human behaviour is determined by hormones, genes and synapses [...] how much longer can we maintain the wall that separates the biology department from the faculty of human sciences?'

\section{The dimensions of intergenerational capital}

The third contribution made by this framework is that it highlights several levels of identity concerns during intergenerational transmission. These are agentic (linked to personal identity), familial (linked to family identity) and communal (linked to the collective identity of a community). In other words, there are several dimensions to intergenerational capital, some of which are individualised, some shared with the whole family and some common to the community of belonging. The communal dimension of intergenerational transmission allows us to understand how elements of intergenerational capital can be transmitted between generations that do not mix with one another (demographic generations).

The agentic, familial and communal levels of intergenerational capital require explanation and clarification. Are they expressed in the same way when it comes to education, solidarity and preservation? The development of reliable and valid measurement tools would enable us to answer these questions. Scales are currently used in heritage research (Guillemot and Urien, 2016; Lacroix and Jolibert, 2015; Urien and Kilbourne, 2011), but they are rooted in a vision of generativity that is mainly based on the preservation desire (McAdams and de St Aubin, 1992). A return to Erikson's (1959) original theory would allow us to take into account concerns linked to education and taking care. 


\section{CONCLUSION}

The aim of this article was to propose a conceptual framework of intergenerational transmission that integrates all the existing consumer behaviour knowledge on the subject. An Eriksonian interpretation of intergenerational transmission highlighted four positions that individuals can occupy in relation to their intergenerational capital, which are to absorb it, to differentiate from it, to take care of it and to preserve it. Current knowledge on these four positions clarifies the nature of intergenerational capital by distinguishing sociocultural, economic, psychological and genetic resources. Similarly, the literature has highlighted the individual, familial and communal dimensions of intergeneration capital.

This conceptual framework thus offers a more complete vision of intergenerational transmission. It also opens up new research perspectives. Salient among those presented in the discussion section are studies of the relationships of interactions between the different components of intergenerational capital that take into account material living conditions, psychological variables such as self-esteem and self-confidence and/or which develop methodologies based on sibling comparisons. There is also a need to develop knowledge to support individuals in the individualisation of their sociocultural capital in a context in which consumer practices linked to digital and energy transitions are undergoing a dramatic change. In addition, it is essential to gain a better understanding of the difficulties faced by the 'pivot' generation when it has to take care of its intergenerational capital. Finally, we need to develop instruments for measuring the different developmental concerns linked to intergenerational transmission.

This new knowledge can now be developed within a common framework. The dispersal of knowledge using various keywords highlights a limitation of this research. Only those studies with the keywords 'socialisation', 'influences', 'learning' 'heritage', 'exchanges', 'gifts' and 'legacies' (and their French equivalents) were considered. This could explain the absence of certain studies in the literature review presented above. For example, some of the research on ethnic consumption could have been included given a good number of studies consider a 'heritage' dimension (Özçăglar-Toulouse et al., 2009). Moreover, other studies in tourism/cultural marketing show that websites/museums are valorised for their ability to preserve and showcase collective heritages and shared histories (Bourgeon-Renault et al., 2009; Leong et al., 2015). All these studies could enrich our understanding of the communal dimension of intergenerational capital, which allows us to explain the transmissions between demographic generations.

In any case, we hope that this conceptual framework will enable researchers to better understand the phenomena of intergenerational transmission and to develop new knowledge. This is a key subject that impacts today's society and responds to the challenges of tomorrow's, which are to educate young consumers, to support them to adopt sustainable consumer practices and to take care of and preserve aspects of intergenerational capital in the current context of economic precariousness and an ageing demographic.

\footnotetext{
Acknowledgements: The authors would like to thank the three anonymous reviewers and the editor-in-chief for their very constructive comments and suggestions, which have contributed to improving the quality of this article. He is also very grateful for all their encouragement and support. My thanks also to Marine Le Gall-Ely, Andréa Gourmelen, Bertrand Urien, Sylvie Codo and Annick Tamaro for all their shrewd comments and advice.
} 


\section{BIBLIOGRAPHY}

Arndt J (1971) A research note on intergenerational overlap of selected variables. Markeds Kommunikasjon 3: 1-8.

Attias-Donfut C (2000) Rapports de générations. Transferts intrafamiliaux et dynamique macrosociale. Revue française de sociologie 41(4): 643-684.

Attias-Donfut C and Segalen M (1998) Grands-parents. La famille à travers les générations. Paris: Editions Odile Jacob.

Arrondel L and Masson A (2011) Taxer les héritages pour accroitre la mobilité du patrimoine entre générations. Revue française d'économie. XXVI(2): 23-72.

Axim WG, Pearce LD and Ghimire D (1999) Innovations in life history calendar applications. Social Science Research 28: 243-264.

Ayadi K and Gollety M (2012) La famille : un lieu d'échanges privilégiés pour apprendre à consommer. In: Bree J. (ed.) Kids Marketing. 2eme edition, Caen: Editions EMS, 149-176.

Beatty SE and Talpade S (1994) Adolescent influence in family decision making: a replication with extension. Journal of Consumer Research 21(September): 332-41.

Belk RW (1988) Possessions and the extended self. Journal of Consumer Research 15(2): 139168.

Belk RW (2013) Extended self in a digital world. Journal of Consumer Research 40(3): 477-500.

Belk RW, Sherry J-F Jr and Wallendorf M (1988) The sacred and the profane in consumer behavior: theodicy on the Odyssey. Journal of Consumer Research 16(June): 1-38.

Bourcier-Bequaert B and de Barnier V (2010) Toward a larger framework of the generation concept in marketing. Recherche et Applications en Marketing (English Edition) 25(3): 115135.

Bourdieu P (1979) La distinction : critique sociale du jugement. Paris: Les Editions de Minuit.

Bourdieu P (1994) Raisons pratiques sur la théorie de l'action. Paris: Editions du Seuil.

Bourgeon-Renault D, Urbain C, Gombault A, Le Gall-Ely M and Petr C (2009) Gratuite et valeur attachée a l'objet de consommation culturelle : le cas des musées et des monuments Décisions Marketing 54(Avril-Juin): 51-62.

Bowbly J (1978) Attachement et perte, vol. 1: L'attachement. Paris: PUF.

Bradford TW (2009) Intergenerationally gifted asset dispositions. Journal of Consumer Research 36(1): 93-111.

Butler RN (1963) The Life Review: an interpretation of reminiscence in the age. Psychiatry 26: $65-75$.

Cai Y, Zhao G and He J (2015) Influences of two modes of intergenerational communication on brand equity. Journal of Business Research 68(3): 553-560.

Carlson L and Grossbart S (1988) Parental style and consumer socialization of children. Journal of Consumer Research 15(1): 77-94.

Carlson L, Walsh A, Laczniak R and Grossbart S (1994) Family communication patterns and marketplace motivations, attitudes, and behaviors of children and mothers. Journal of Consumer Affairs 28: 25-53.

Castano R, Perez ME and Quintanilla C (2010) Crossborder shopping: family narratives. Qualitative Market Research 13(1): 45-57.

Chaplin LN and Roedder-John D (2010) Interpersonal influences on adolescent materialism: A new look at the role of parents and peers. Journal of Consumer Psychology 20: 176-184.

Childers TL and Rao AR (1992) The influence of familial and peer-based reference groups on consumer decisions. Journal of Consumer Research 19(2): 198-211.

Cordier M, Houdre C and Ruiz H (2007) Transferts intergénérationnels entre vifs : aides et donations. INSEE Première : $\mathrm{n}^{\circ} 1127$.

Cotte J and Wood SL (2004) Families and innovative consumer behavior: a triadic analysis of sibling and parental influence. Journal of Consumer Research 31(1): 78-86. 
Cours D, Heisley DD, Wallendrorf M and Johson D (1999) It's all in the family, but I want it. In: Arnould E and Scott L (eds) Advances in Consumer Research 26: 253-29.

Curasi CF (2011) Intergenerational possession transfers and identity maintenance. Journal of Consumer Behaviour 10(2): 111-118.

Curasi CF, Price LL and Arnould EJ (2004) How individuals' cherished possessions become families' inalienable wealth. Journal of Consumer Research 31(3): 609-622.

Decoopman I and Gentina E (2013) La propension des mères à échanger des vêtements avec leur fille adolescente : quelle conséquences pour le marketing ? Décisions Marketing 70: 75-90.

Derbaix M, Derbaix C, Kindt M, Korchia M and Luna Fernandez M (2016) Transmissions culturelles entre parents et enfants : le cas des gouts musicaux. Management \& Avenir 87(5): $151-174$.

Derbaix C, Leheut E, Kindt M and Boi L (2015) Les grands-parents : agents d'une socialisation spécifique de leurs petits-enfants consommateurs ? Revue Française du Marketing 252: 7-22.

Downey $\mathrm{H}$ and Ellis S (2008) Tails of animal attraction: incorporating the feline into the family. Journal of Business Research 61(5): 434-441.

Epp AM and Price LL (2010) The storied life of singularized objects: forces of agency and network transformation. Journal of Consumer Research 36(5): 820-837.

Erikson E (1950) Childhood and Society. New York: Norton \& Co.

Erikson E (1959) Identity and the life cycle: selected paper. Psychological Issues 1: 50-100.

Felfoul KS (2014) Le rôle de la famille dans le développement du matérialisme : une étude basée sur le paradigme du parcours de vie. Thèse de Doctorat: Université de Laval, Québec.

Gale WG and Schultz JK (1994) Intergenerational transfers and the accumulation of wealth. Journal of Economic perspective 38: 145-160.

Gentina E, Decoopman I and Ruvio A (2013) Social comparison motivation of mother's with their adolescent daughters and its effects on the mother's consumption behavior. Journal of Retailing and Consumer Services 20: 94-101.

Gire P (2003) Epistémologie du concept de transmission. In: Rodet C (ed.) La transmission dans la famille : secrets, fictions et idéaux. Paris: L'Harmattan, 19-24.

Gollety M (1999) Lorsque parents et enfants s'apprennent mutuellement à consommer... Décisions Marketing 18: 69-80.

Gollety M, Guichard N et Ayadi K (2012) La consommation dans la famille : des influences de nature différente. In: Bree J (ed.) Kids Marketing. 2eme edition, Caen: Editions EMS, 223-254.

Grayson K and Shulman D (2000) Indexical and the verification function of irreplaceable possessions: A semiotic analysis. Journal of Consumer Research 27(1): 17-30.

Guillemot S (2015) La transmission intergénérationnelle : regard sur les services aux particuliers. Revue Management \& Avenir 77(3):51-69.

Guillemot S and Urien B (2010) Legacy writing among the elderly: conceptual bases, dimensioning and a proposed scale for measuring motivations. Recherche et Applications en Marketing (English Edition) 25(4): 25-43.

Guillemot S and Urien B (2016) Legacy writing and the consumption of biographic services. Psychology \& Marketing 33(11): 971-981.

Harari YN (2015) Sapiens, une brève histoire de l'humanité. Paris: Albin Michel.

Heckler SE, Childers TL and Arunachalam R (1989) Intergenerational influences in adult buying behaviors: an examination of moderating factors. In: Srull TK (ed.) Advances in Consumer Research 16: 276-284.

Hemar-Nicolas V and Rodhain A (2012) Pour un Kids Marketing responsable !!! In: Bree J (ed.) Kids Marketing. 2eme edition, Caen: Editions EMS, 71-116.

Hirschman EC (1985) Primitive aspects of consumption in modern American society. Journal of Consumer Research 12(2): 142-154. 
Johnson W, Turkheimer E, Gottesman I and Bouchard T (2009) Beyond heritability: twin studies in behavioral research. Current Directions in Psychological Science 18(4): 217-220.

Josion-Portail M (2014) Comment parents et grands-parents influencent l'apprentissage du bien manger chez l'enfant : Contribution de la transmission intergénérationnelle dans le contexte de la consommation alimentaire. Thèse de doctorat en sciences de gestion: Université de Paris 1.

Josion-Portail M and Michel G (2016) Comment favoriser la transmission intergénérationnelle du "bien manger"? Vers de nouveaux leviers au service des pouvoirs publics. Actes du 32eme congrès de l'Association Française de Marketing, Lyon.

Karanika K and Hogg M (2016) Consumption through the ambivalent prism of intergenerational support. European Journal of Marketing 50(3/4): 575-601.

Kaes R, Faimberg H, Enriquez and Baranes J-J (2003) Transmission de la vie psychique entre générations. 2eme édition, Paris: Dunod.

Kessous A, de Barnier V and Valette-Florence P (2015) «A la recherche du temps perdu » : la transmission d'objets de luxe de père en fils, entre cadeau et fardeau. Décisions Marketing 80: $17-34$.

Kessous A and Chalamon I (2014) La transmission de remèdes de grand-mères de mère en fille : une extension temporelle de soi. Décisions Marketing 76: 61-73.

Kim C, Lee H and Tomiuk MA (2009) Adolescents' perceptions of family communication patterns and some aspects of their consumer socialization. Psychology \& Marketing 26(10): 888-907.

Krebs A, Rieunier S and Urien B (2012) Le legs aux organismes culturels : identification du testateur et pratiques managériales. In: Guiot $\mathrm{D}$ and Urien $\mathrm{B}$ (eds) Comprendre le consommateur âgé, nouveaux enjeux et perspectives. Bruxelles: De Boeck 157-178.

Lacroix C and Jolibert A (2015) Targeting consumers who care about future generations. Psychology \& Marketing 32(8): 783-794.

Ladwein R, Carton A and Sevin E (2009) Trans-Generational Equity: The Transmission of Consumption Practices between Mother and Daughter. Recherche et Applications en Marketing (English Edition) 24(2):1-27.

Lahaye W, Poutois J-P and Desmet H (2007) Transmettre d'une génération à l'autre. Paris: PUF.

Lastovicka JL and Fernendez KV (2005) Three paths to disposition: the movement of meaningful possessions to strangers. Journal of Consumer Research 31(March): 813-23.

Lee E, Mathur A, Kwai Fatt C and Moschis GP (2013) The timing and context of consumer decisions: insights from the life course paradigm. Marketing Letters 23(3): 793-805.

Leong AW, Yeh S, Hsiao Y and Huan TT (2015) Nostalgia as travel motivation and its impact on tourists' loyalty. Journal of Business Research 68(1): 81-86.

Lueg JE, Ponder N, Beatty SE and Capella ML (2006) Teenagers' use of alternative shopping channels: a consumer socialization perspective. Journal Of Retailing 82(2):137-153.

Mahur H and Moschis GP (1999) Exploring the intergenerational caregiver market: a study of family care providers for the elderly. Journal of Marketing Theory and Practice 7(3):76-86.

Malas Z and Guiot D (2010) Une mesure de la Valence de la perspective / Future (VPF) des personnes âgées : conséquences sur les choix financiers. Revue Sciences de Gestion 76: 65-91.

Malas Z (2012) Le rapport à l'avenir du consommateur âgé : entre épargne et consommation. In: Guiot D and Urien B (eds) Le consommateur âgé. Bruxelles: De Boeck, 51-66.

Mandrik CA, Fern EF and Bao Y (2005) Intergenerational influence: roles of conformity to peers and communication effectiveness. Psychology \& Marketing 22(10): 813-832.

Masson A (2009) Des liens et des transferts entre générations. Paris: Editions EHESS.

McAdams DP (2001) Generativity in midlife. In: Lachman ME (ed.) Handbook of Midlife Development. New York: Wiley, 395-443. 
McAdams DP and de St Aubin E (1992) A theory of generativity and its assessment through selfreport, behavioral acts, and narrative themes in autobiography. Journal of Personality and Social Psychology 62:1003-1015.

McCracken G (1988) Lois Roget: curatorial consumer in a modern world. In: McCraken G (ed.) Culture and Consumption. Bloomington: Indiana University Press, 44-56.

Moore-Shay ES and Lutz RJ (1988) Intergenerational influences in the formation of consumer attitudes and beliefs about the marketplace: mothers and daughters. Advances in Consumer Research 15(11): 461-467.

Moore ES, Wilkie WL and Lutz RJ (2002) Passing the torch: intergenerational influences as a source of brand equity. Journal of Marketing 66(2): 17-37.

Moschis GP and Churchill GA Jr (1978) Consumer socialization: a theoretical and empirical analysis. Journal of Marketing Research 15(4): 599-609.

Moschis GP and Moore RL (1979) Family communication and consumer socialization. Advances in Consumer Research 6(1): 359-363.

Moschis GP, Moore RL and Smith RB (1984) The impact of family communication on adolescent consumer socialization. Advances in Consumer Research 11(1): 314-319.

Nancarrow C, Tinson J and Brace I (2008) Consumer savvy and intergenerational effects. International Journal of Market Research 50(6): 731-755.

Noble SM, Schewe CD and Kuhr M (2004) Preferences in health care service and treatment: A generational perspective. Journal of Business Research 57(9): 1033-1041.

Obermiller C and Spangenberg ER (2000) On the origin and distinctness of skepticism toward advertising. Marketing Letters 11(4): 311-322.

Olsen B (1999) Exploring women's brand relationships and enduring themes at mid-ife. In: Arnould E and Scott LM (eds) Advances in Consumer Research 26: 615-620.

Ozcăglar-Toulouse N, Beji-Becheur A, Fosse-Gomez M, Herbert M and Zouaghi S (2009) Ethnicity in the Study of the Consumer: an Overview. Recherche et Applications en Marketing (English Edition) 24(4): 57-76.

Piketty T (2013) Le capital au XXIe siècle. Paris: Editions du Seuil.

Plomin R, DeFries J, McClean G and Rutter M (1999) Des gènes au comportement, introduction à la génétique comportementale. 3eme édition Bruxelles: DeBoeck University.

Preel B (2005) Les générations mutantes : Belle époque, krach, mai 68, Internet, quatre générations dans l'histoire. Paris: La Découverte.

Price LL, Arnould EJ and Curasi CF (2000) Older consumers' disposition of special possessions. Journal of Consumer Research 27(2): 179-201.

Richins ML (1994) Valuing things: the public and private meaning of possessions. Journal of Consumer Research 21(December): 504-521.

Richins ML and Chaplin LN (2015) Material parenting: how the use of goods in parenting fosters materialism in the next generation. Journal of Consumer Research 41:1333-1357.

Rieunier S and Urien B (2011) Léguer, c'est continuer a vivre. In: Bergadaa M, Le Gall-Ely M and Urien B (eds) Don et pratiques caritatives. Bruxelles: De Boeck University. 177-195.

Rindfleisch A, Burroughs JE and Denton F (1997) Family structure, materialism, and compulsive consumption. Journal of Consumer Research 23(4): 312-325.

Rindfleisch A, Burroughs JE and Wong N (2009) The safety of objects: materialism, existential insecurity, and brand connection. Journal of Consumer Research 36(1): 1-16.

Roberts JA, Manolis C and Tanner JF Jr (2003) Family structure, materialism and compulsive buying: a reinquiry and extension. Academy of Marketing Science 31(3): 300-311.

Roedder John D (1999) Consumer socialization of children: a retrospective look of twenty-five years of research. Journal of Consumer Research 26(December): 183-213.

Schindler RM, Lala V and Corcoran C (2014) Intergenerational influence in consumer deal proneness. Psychology \& Marketing 31(5): 307-320. 
Shah RH and Mittal B (1997) Toward a theory of intergenerational influence in consumer behavior: an exploratory essay. Advances In Consumer Research 24(1): 55-60.

Siddiqui K, Bashir S, Sarki IH, Jaffari SIA and Abbas S (2012) Intergenerational influences on brand preferences: consumables vs durables. International Journal of Business and Social Science 13(3): 227-231.

Simonson I and Sela A (2011) On the heritability of consumer decision making: an exploratory approach for studying genetic effects on judgment and choice. Journal of Consumer Research 37(6): 951-966.

Stevenson GJ and Kates SM (1999) The last gift: the meanings of gift-giving in the context of dying of AIDS. In: Arnould EJ and Scott L (eds) Advances in Consumer Research 26: 113-18.

Tavoillot P-H, Attias-Donfut C, Masson A, Van de Velle C and Guerin S (2011) Métarevue sur le lien intergénérationnel : Etat des savoirs et Etat des débats. Paris: Campus Lab MACIF.

Trizzulla C, Garcia-Bardidia R and Remy E (2016) From Bourdieu to Lahire: Social determinism and pluralist consumer practices. Recherche et Applications en Marketing (English Edition) 31(1): 87-105.

Turkheimer E (2000) Three laws of behavior genetics and what they mean. Current Directions in Psychological Science 9(5): 160-64.

Urien B (2003) L'anxiété face à la mort et son influence sur le comportement du consommateur. Recherche et Applications en Marketing 18(4): 23-41.

Urien B and Guiot D (2007) Attitude face à la mort et comportement d'ajustement des consommateurs âgés : vers l'élaboration d'une réponse marketing. Décisions Marketing 46 (avril-juin): 23-36.

Urien B and Kilbourne W (2011) Generativity and self-enhancement values in eco-friendly behavioral intentions and environmentally responsible consumption behavior. Psychology \& Marketing 28(1): 69-90.

Vaillant GE (2002) Aging Well. Boston: Little Brown.

Viswanathan M, Childers TL and Moore ES (2000) The measurement of intergenerational communication and influence on consumption: development, validation, and cross-cultural comparison of the IGEN scale. Journal of the Academy of Marketing Science 28(3): 406-424.

Wallendorf M and Arnould EJ (1991) 'We gather together': consumption rituals of Thanksgiving Day. Journal of Consumer Research 18(1): 13-31.

Ward S (1974) Consumer socialization. Journal of Consumer Research 1(September): 1-14.

Ward S, Wackman D and Wartella E (1977) The development of consumer informationprocessing skills: integrating cognitive development and family interaction theories. In: Perreault WD Jr (ed.) Advances in Consumer Research 4: 166-171.

Wiman AR (1983) Parental influence and children's response to television advertising. Journal of Advertising 12(1): 12-18.

Winter J-P (2012) Transmettre (ou pas). Paris: Albin Michel.

Woodson LG, Childers T and Winn PR (1976) Intergenerational influences in the purchase of auto insurance. In: Locander W (ed.) Marketing Looking Outward. Business Proceeding 38. Chicago: American Marketing Association, 43-49.

Young $\mathrm{M}$ and Wallendorf $\mathrm{M}$ (1989) Ashes to ashes, dust to dust: conceptualizing consumer disposition of possessions. American Marketing Association Winter Educators' Conference Proceedings. Chicago: American Marketing Association, 33-39. 